\title{
Physicochemical Characteristics of Honey Samples from Mambilla Plateau, Nigeria
}

\author{
Japhet Amanah Lullah-Deh, Muluh Emmanuel Khan, Ishaq Shaibu Eneji \\ Department of Chemistry, University of Agriculture, Makurdi, Nigeria \\ Email address: \\ japhetlullah@gmail.com(J.A. Lullah-Deh)

\section{To cite this article:} \\ Japhet Amanah Lullah-Deh, Muluh Emmanuel Khan, Ishaq Shaibu Eneji. Physicochemical Characteristics of Honey Samples from \\ Mambilla Plateau, Nigeria.Journal of Biomaterials.Vol. 2, No. 1, 2018, pp. 7-11. doi: 10.11648/j.jb.20180201.12
}

Received: March 11, 2018; Accepted: April 8, 2018; Published: May 14, 2018

\begin{abstract}
This research investigated the physicochemical properties of seven honey samples obtained from seven different locations on the Mambilla Plateau.The physicochemical properties evaluated were colour, temperature, $\mathrm{pH}$, moisture contents, viscosity, specific gravity, density and conductivity. The results showed a range of honey colours from light amber to dark, $\mathrm{pH}$ range of $(3.22-5.00)$; temperature range of $\left(29.0-39.4{ }^{\circ} \mathrm{C}\right)$; moisture content range of $(16.4-34.0 \%)$; viscosity range of $(23.2-34.7 \mathrm{Ns} / \mathrm{m})$; specific gravity range of $(1.35-1.47)$; density range of $\left(1.30-1.51 \mathrm{~g} / \mathrm{cm}^{3}\right)$; and conductivity range of $(7.6$ $-12.4 \mu \mathrm{s} / \mathrm{m})$.
\end{abstract}

Keywords: Physicochemical, Honey, Samples, Parameters

\section{Introduction}

Honey is a sweet and flavorful natural product, which is consumed due to its health values. Honey is produced by Bees from plant nectars, plant secretions and excretions of plant-sucking insects. It represents an interesting source of natural macro and micro-nutrients, saturated solution of sugar (fructose and glucose) and also a wide range of minor constituents like phenolic compounds [1, 2]. It contains antioxidant, bacteriostatic, anti-inflammatory, antimicrobial properties, including wound and sunburn healing effects [3].

Honey can be characterized according to its geographical origin. It has been reported that honey samples showed regional variations in the physicochemical parameters such as $\mathrm{pH}$, ash content, enzymes activities, hydroxymethylfurfural and electrical conductivity [4].

Colour: The color of the honey samples depends on the floral source, phenolic compounds and the temperature. Darker honeys are rich in antioxidant. The colour of the honey samples ranges from light amber through dark amber to dark [5].

Temperature: The temperature influences the storage of honey. Honey is sensitive to heat when honey is exposed to temperature of $100^{\circ} \mathrm{C}$ for 5 minutes, $80^{\circ} \mathrm{C}$ for 10 minutes, $56^{\circ} \mathrm{C}$ for 30 minutes losses it's antibacterial activity by $17 \%$ [6]. At temperature $85^{\circ} \mathrm{C}$, can inactivate diastase and break down hydrogen peroxide.

$\mathrm{pH}$ : The $\mathrm{pH}$ of a solution is the hydrogen concentration of that solution. Honey has low $\mathrm{pH}$ values which range from 3.0-4.9 that can decrease diastase activity, below the optimum $\mathrm{pH}$ values range of 5.3-5.6. Literature revealed that the $\mathrm{pH}$ values investigated in honey samples from some areas were Unayza (4.58) [7], Lagos (4.93) [8], Ogun (4.55) and Osun (5.05). Mateo and Bosch-Reig[9] reported that honey samples with a $\mathrm{pH}$ value of $\mathrm{pH} \leq 4$ are good honey.

Moisture content: The moisture content is the most important physicochemical property of honey because it affects storage life. Low moisture content is one of the antimicrobial properties of honey [10]. The water activity of ripened honey ranges from 0.56-0.62 does not support the growth of bacteria and yeasts, and the range of 0.94-0.99 support the growth of bacteria and yeasts as well as crystallization and fermentation [11].The moisture content of honey samples revealed to be $(30.3,27.7,13.35 .31 .54$ and $28.465 \%$ ) obtained from Osun, Oyo, Lagos, Ogun and Ekiti, recorded by Adebiyiet al. [8]. The guide line limit of honey samples set internationally $(<21 \%)[5]$.

Viscosity: Honey samples with high viscosity is described as a high quality honey. Viscosity of honey is a contributory factor of the antimicrobial property of honey [12]. Viscosity limits dissolved oxygen and other chemical agents in the honey solution (glucose, fructose and sucrose), low water activity, low temperature and low moisture content. The 
viscosity values of some honey samples recorded by Oladipupo and Isah[13] were (56.262, $41.174 \mathrm{Ns} / \mathrm{m})(49.689$ $\mathrm{Ns} / \mathrm{m})(37.888 \mathrm{Ns} / \mathrm{m})$, obtained from Kachia, Gidan-Waya and Anchau in Kaduna State.

Specific Gravity: The specific gravity of honey varies with chemical composition of the honey [14](Bath and Singh, 1997). The specific gravity values of samples obtained in Benghazi were $\left(1.405 \mathrm{~g} / \mathrm{cm}^{3}, 1.2086 \mathrm{~g} / \mathrm{cm}^{3}, 1.2081 \mathrm{~g} / \mathrm{cm}^{3}\right.$ and $1.2270 \mathrm{~g} / \mathrm{cm}^{3}$ ) for samples $1,2,3$ and 8 respectively from Libya[15]. The guideline limit for specific gravity property of honey has not been established by the international organization [16].

Density: The density of honey samples can be low and high. Honey samples with high density value is described as a good natural honey. Pycnometric method can be used to determine the density of a good honey using Equation 1:

$$
p=\frac{W_{2}-W_{1}}{v\left(\mathrm{~cm}^{3}\right)}
$$

Where $\mathrm{W}_{1}=$ mass of empty pycnometer; $\mathrm{W}_{2}=$ mass of honey samples + pycnometer; $\mathrm{V}=$ volume of the pycnometer[17]. The density values of some honey samples $\left(1.425 \mathrm{~kg} / \mathrm{m}^{2}, \quad 1.396 \mathrm{~kg} / \mathrm{m}^{2}, \quad 1.366 \mathrm{~kg} / \mathrm{m}^{2}\right.$, and $\left.1.398 \mathrm{~kg} / \mathrm{m}^{2}\right)$ obtained from Kachia, Zonkwa, and Gidan-Waya of Kaduna State were a good honey with high density values[13].

Electrical conductivity: The electrical conductivity of a given honey samples is based on the contents of inorganic salts, organic acids, complex sugars and polyols including the minerals contents [14]. The electrical conductivity of some honey samples $(0.31 \mathrm{~ms} / \mathrm{m}, 0.34 \mathrm{~ms} / \mathrm{m}, \quad 0.27 \mathrm{~ms} / \mathrm{m}$, and $0.53 \mathrm{~ms} / \mathrm{m}$ ) obtained from Ayeye, Apata, Omi-Adio, Iwo Road and Bere all from Ibadan reported by Lawalet al. [18]. The limit set by European legislation $(<0.8 \mu \mathrm{s} / \mathrm{cm})[16]$.

\section{Materials and Methods}

\subsection{Materials}

\subsubsection{Chemicals and Reagents}

Distilled/de-ionized water, Conc. $\mathrm{HCl}$ acid (35.5\%), Conc. $\mathrm{HNO}_{3}$ acid $(70 \%), \mathrm{KCl}(99.5 \%)$ and $\mathrm{NaOH}(99 \%)$. All the chemicals and reagents were of analytical grade purchased from World Corsica Limited, No. 5 Benue Crescent, Wadata, Makurdi, Benue State.

\subsubsection{Apparatus and Equipment}

Measuring cylinders $(500 \mathrm{~mL}, 50 \mathrm{~mL}$ and $10 \mathrm{~mL})$; Boiling tubes; Beakers (250 mL, $100 \mathrm{~mL}$ and $50 \mathrm{~mL})$; Wooden/glass rod stirrers; Petri dish; Crucible; Stop watch; $\mathrm{pH}$ meter (HANNA instruments, HI 96107 model, made in Italy); Empty polyethylene bottles; $50 \mathrm{ml}$ density bottles; Analytical weighing balance; Oven; Viscometer (Brookfiled viscometer model RVDVE serial No. 8488113); Hot plate/burner; Conductivity meter (HANNA instrument USA made in Romania. HI 98129); Funnel; Volumetric flask (250 mL, 500 $\mathrm{mL}$ and $1000 \mathrm{~mL}$ ); Laboratory Thermometer; Atomic Absorption spectrometer (Thermo scientific 3000 series) and Laboratory coat and protective eye glass.

\subsection{Methods}

\subsubsection{Sample Collection}

Samples are true representatives of the entire study area.The honey samples were collected from seven locations (five from the bee-farmers and two market samples) from April - June and November, 2016 for investigation.The samples collected were all on Mambilla Plateau, Sardauna Local Government Area of Taraba State.The samples were put separately in cleaned high density polythene sampling bottles before they were transported to the laboratory for analysis.The sampling areas were Maisamari, $76.6 \mathrm{~km}$ from Gembu the Headquarters of the Local Government, Kakara, $18 \mathrm{~km}$ from Gembu, Dorofi, $25.2 \mathrm{~km}$ from GembuKan-Iyaka, $52.3 \mathrm{~km}$ from Gembu, Mbamnga, $15.2 \mathrm{~km}$ from Gembu, Nguroje, $21 \mathrm{~km}$ from Gembu and Gambu the Administrative Headquarters.

\subsubsection{Storage and Preservation of Sample}

The collected samples were properly stored at room temperature and preserved to avoid loss due to poor storage, were timely analyzed to minimize loss due to prolonged storage. Samples were stored in polyethylene bottles or amber bottles preserved for analysis [19].

\subsubsection{Determination of Physicochemcial Parameters}

The physicochemical parameters were determined in accordance with the procedures outlined in the standard method for the examination of water and waste water [19, 20].

\section{(i) Determination of Temperature}

Exactly $50 \mathrm{~mL}$ of each of the samples was measured and separately transferred into a beaker; a laboratory thermometer was inserted to determine the temperature of the individual sample. This was determined at the point of sampling. The readings on the thermometer were recorded [19].

\section{(ii) Determination of Electrical Conductivity}

This was determined by measuring $20 \mathrm{~g}$ of honey and dissolved in $100 \mathrm{~mL}$ of distilled water mixed thoroughly to form solution. Electrical conductivity meter (HANNA instrument USA made in Romania. HI 98129) was immersed. The instrument was calibrated using potassium chloride $(\mathrm{KCl})$ dissolved in water (de-ionized) and made up to 1 litre to be used as the standard reference solution [20]. The readings were recorded.

\section{(iii) Determination of Density}

The pycnometry method was used to determine the density of the honey samples using the expression below;

$$
p=\frac{\left[W_{2}-W_{1}\right] g}{V\left(\mathrm{~cm}^{3}\right)}
$$

Where: $\mathrm{W}_{1}=$ mass of the pycnometer when empty; $\mathrm{W}_{2}=$ mass of the pycnometer filled with honey sample; $\mathrm{V}=$ 
volume of the pycnometer[21].

\section{(iv) Determination of $\mathrm{pH}$}

The $\mathrm{pH}$ of the honey sample was measured using a $\mathrm{pH}$ meter (HANNA instruments HI 96107 model, made in Italy), from a solution containing $20 \mathrm{~g}$ of honey in $75 \mathrm{~mL}$ of deionized water. The readings were recorded for each and every sample [20].

\section{(v) Determination of Moisture Contents}

The moisture content of each honey sample was determined by measuring $5 \mathrm{~g}$ of the sample and placed into a pre-weighed aluminum drying dish.The sample was dried to constant weight in an oven at $105^{\circ} \mathrm{C}$ for four hours under vacuum $[22,23]$.

$$
\text { Moisture content }=\frac{M_{1}-M_{2}}{M_{1}-M_{0}}
$$

Where: $M_{0}=$ weight of aluminum dish; $M_{1}=$ weight of the fresh sample + dish; $M_{2}=$ weight of the dried sample + dish

\section{(vi) Determination of Colour}

Determination of colour was carried out using a colour comparator.Clear blanks were placed in compartments, 1, 3, 5 of the comparator.The honey samples were also placed in compartment 2 or 4 of the comparator. The comparator was held at a convenient distance from the eye and viewed by diffused light.The samples were moved from compartment to compartment until the samples equal or match the standard [20].

\section{(vii) Determination of Specific Gravity}

The specific gravity was obtained as the ratio of the weight of sample to that of equal volume of water [20].

$$
S G=\frac{W_{s b}-W_{b}}{W_{w b}-W_{b}}
$$

Where: $\mathrm{W}_{\mathrm{b}}=$ Weight of the pycnometer; $\mathrm{W}_{\mathrm{sb}}=$ Weight of the sample + pycnometer; $\mathrm{W}_{\mathrm{wb}}=$ Weight of water + pycnometer.

\section{(viii) Determination of Viscosity}

The viscosity of the honey samples was determined by using viscometer (Brookfield viscometer (model RVDVE serial No.8488113), using spindle No.4. The viscosity was recorded in centipoises (CP) [20].

\section{Results}

The results of the physicochemical parameters analyzed are shown in Table 1.

\begin{tabular}{|c|c|c|c|c|c|c|c|c|}
\hline \multirow{2}{*}{ Parameters } & \multicolumn{5}{|c|}{ Sample from bee farmers } & \multicolumn{2}{|c|}{ Market sample } & \multirow{2}{*}{ Mean \pm SD } \\
\hline & MS & KK & DF & KI & MG & GB & NG & \\
\hline Temperature $\left({ }^{\circ} \mathrm{C}\right)$ & 30.3 & 31.8 & 39.4 & 36.6 & 32.4 & 29.1 & 29.0 & $32.7 \pm 3.7$ \\
\hline $\mathrm{PH}$ & 3.70 & 5.00 & 3.22 & 3.68 & 3.44 & 3.84 & 3.92 & $33.83 \pm 0.53$ \\
\hline Density $\left(\mathrm{g} / \mathrm{cm}^{3}\right)$ & 1.51 & 1.45 & 1.40 & 1.30 & 1.48 & 1.40 & 1.40 & $1.42 \pm 0.06$ \\
\hline Moisture content (\%) & 22.2 & 34.0 & 16.4 & 20.8 & 19.8 & 24.6 & 30.4 & $24.0 \pm 5.4$ \\
\hline Specific gravity & 1.42 & 1.41 & 1.43 & 1.35 & 1.467 & 1.38 & 1.38 & $1.41 \pm 0.03$ \\
\hline Viscosity (Ns/m) & 27.1 & 23.2 & 34.7 & 28.5 & 32.6 & 26.3 & 24.0 & $28.1 \pm 4.0$ \\
\hline
\end{tabular}

Table 1. Physicochemical parameters of honey samples from seven locations.

\section{Discussion}

\subsection{Colour}

The results of the physicochemical analysis revealed that the colour of the honey samples varied from light amber, through dark amber to dark. These colours were also the same with the colour of the honey samples obtained from market samples. These colours were also the same with the colours of honey samples reported by Lawalet al. [18] obtained from Ayeye, Apata, Omi-Adio, Iwo-Road and OkeAdo in Ibadan, Nigeria. Comparatively, the colours obtained both from the bee-farmers and the market samples were within the prescribed colours set internationally [24].

\subsection{Temperature}

The temperature of honey samples analyzed ranged from 29.0-39. $4^{\circ} \mathrm{C}$, with mean $\pm \mathrm{SD}$ of $32.7 \pm 3.7$. There was no significant difference $(\mathrm{p} \leq 0.05)$ in the temperature of honey samples obtained from the study area.The market samples had the lowest temperature values when compared to the temperature values investigated for samples collected from bee farmers. These temperature values were below the temperature value of $85^{\circ} \mathrm{C}$ that can inactivate, denature enzymes and break down hydrogen peroxide when honey samples are being exposed to it for 5 minutes as reported by Babacanet al. [6].

\section{3. pHValue}

The $\mathrm{pH}$ of the honey samples ranged from 3.22-5.00 with mean $\pm \mathrm{SD}$ of $3.83 \pm 0.53$. There was no significant difference $(\mathrm{p} \leq 0.05)$ in the $\mathrm{pH}$ of the honey samples obtained from the present study. The $\mathrm{pH}$ values of the market samples were higher than the $\mathrm{pH}$ values for samples from Mbamnga, KanIyaka, Dorofi and Maisamari and all were below the data reported $(\mathrm{pH} \leq 4)$ by Perez-Aguillueet al. [25] and [9]. The 
$\mathrm{pH}$ values for this study area were also lower than those values investigated for samples from Lagos, Osun, Ogun, $(4.93,5.05,4.55)$ except $\mathrm{pH}$ value from Kakara, (Figure 3) that was closed to the $\mathrm{pH}$ value obtained from $\operatorname{Osun}[8,26]$. Even the $\mathrm{pH}$ value of sample from Unayza (4.58) Al-Qassim region of Saudi Arabia reported bySanzetal. [7] were higher than the values obtained from this study area. Hence, the honey from the present study area is better because of low $\mathrm{pH}$ concentrations.

\subsection{Moisture Content}

The results of the physicochemical analysis of honey samples revealed that the moisture content obtained ranged from $16.4-34.0 \%$ with mean \pm SD of $24.0 \pm 5.4$. There was a significant difference $(\mathrm{p}>0.05)$ in the values obtained from the study area. These values were higher than the values 15.7, $14.8,14.45$, and $15.95 \%$ obtained from Buridah, Uyanza, AlMalida and Al-Midhnab in Saudi Arabia [7]. Most of the values obtained from this study area were lower than the values $30.28 \%, 27.17 \%, 31.35 \%, 31.54 \%$ and $28.46 \%$ obtained from Osun, Oyo, Lagos, Ogun and Ekiti, reported by Adebiyiet al. [8]. Also most of the values obtained from the study area were within the limit $(<21 \%)$ [5]set internationally. The market samples and few samples obtained from bee farmers indicated little adulteration. These values were below the water activity of ripened honey $(0.56-$ $0.62)$, that does not support the growth of yeasts but the range $(0.94-0.99)$, support the growth of yeasts and bacteria as well as crystallization and fermentation [10, 21].

\subsection{Viscosity}

The viscosity values of the honey samples investigated ranged from $23.2-34.7 \mathrm{Ns} / \mathrm{m}$ with mean $\pm \mathrm{SD}$ of $28.1 \pm 4.0$. There was a significant difference $(p>0.05)$ in the values obtained from the study area. The values obtained from the market samples were lower than the values recorded for samples collected from bee farmers, except Kakara having the least $(23.2 \mathrm{Ns} / \mathrm{m})$. The viscosity values of the study area were lower than the values (56.262 and $41.174 \mathrm{Ns} / \mathrm{m})$, $(49.689 \mathrm{Ns} / \mathrm{m}),(37.888 \mathrm{Ns} / \mathrm{m})$ reported by Oladipupo and Isah [13], who investigated in honey samples from Kachia, Gidan-Waya, Anchau in Kaduna State. However, the present study area recorded high viscosity values. The high viscosity of honey is one of the properties of honey that maintains its antimicrobial activity.

\subsection{Specific Gravity}

The specific gravity values obtained ranged from 1.35-1.47, with the mean \pm SD of $1.41 \pm 0.03$. There was no significant difference $(p<0.05)$ in the values of honey samples obtained from the study area. These values were higher than the values $\left(1.2105 \mathrm{~g} / \mathrm{cm}^{3}, 1.2081 \mathrm{~g} / \mathrm{cm}^{3}\right.$ and $\left.1.2270 \mathrm{~g} / \mathrm{cm}^{3}\right)$ investigated for four different samples by El-Aab and Al-Amrony[15] from Benghazi in Libya. There were little variations in the specific gravity values of the market samples and those obtained from bee farmers. The variation in the specific gravity might be due to variation in the chemical composition [14]. The specific gravity property of honey has not been legislated by the European legislation [16].

\subsection{Density}

The density values for the honey samples investigated ranged from $1.30-1.51 \mathrm{~g} / \mathrm{cm}^{3}$ with mean $\pm \mathrm{SD}$ of $1.42 \pm 0.06$. There was no significant difference $(\mathrm{p} \leq 0.05)$ in the honey samples. The density values obtained from the bee farmers and market samples were high. These values were lower than the values $1.425 \mathrm{~kg} / \mathrm{m}^{2}, 1.366 \mathrm{~kg} / \mathrm{m}^{2}, 1.398 \mathrm{~kg} / \mathrm{m}^{2}$ obtained from Kachia, Zonkwa, Gidan-Waya [13].

\subsection{Electrical Conductivity}

The physicochemical analysis results revealed that the values for electrical conductivity ranged from $7.6 \mu \mathrm{s} / \mathrm{m}$ $12.4 \mu \mathrm{s} / \mathrm{m}$ with the mean $\pm \mathrm{SD}$ of $10.3 \pm 1.5$. There was no significant difference $(\mathrm{p} \leq 0.05)$ in the conductivity values obtained from the present study. The Conductivity values $(0.29-0.74 \mu \mathrm{s} / \mathrm{cm})$ range of Libyan honey reported by ElAab and Al-Amrony [15] were lower than the values obtained from both samples from Bee farmers and the market samples.Further, the values (22.7960), (40.3656, 50.5960), and $(51.7080,54.6548 \mu \mathrm{s} / \mathrm{cm})$ obtained from Kachia, GidanWaya and Zonkwa in Kaduna State. Oladipupo and Isah [13] were also lower than the values obtained from the present study. The results of the conductivity obtained from the present study were higher than the limit set by European Legislation of $<0.8 \mu \mathrm{s} / \mathrm{cm}[16]$. The electrical conductivity of honey samples depends on the content of inorganic salts, organic acids, proteins, complex sugars and polyols including mineral contents in the sample [14].

\section{Conclusion}

This study has demonstrated that the honey samples obtained from Mambilla Plateau, Sardauna Local Government Area of Taraba State can be compared favorably well with other samples from other geographical locations. The physiochemical properties such as $\mathrm{pH}$, moisture content, temperature, viscosity, density, and specific gravity recorded in this study showed that honey from the various locations on thePlateau is of high quality andcan be compared with international acceptable standards, although there was an indication oflittle adulteration by bee farmers and market dealers of honey samples from Kakara, Nguroje, and Gembu, with adulteration values of $34.0 \%, 30.4 \%$ and $24.6 \%$ respectively, however, the values were below the water activity of ripened honey $(0.56-0.62)$. Thus the honey is still fit for consumption.

\section{References}

[1] Bogdanov, S., Jurendic, T,,Sieber,R. and Gallmann, P. (2008). Honey for Nutrition and Health: A Review. Journal of American College of Nutrition, 27(6):677-689. 
[2] Bertoli, E., Battino, M., Alvarez-Suarez, J.M., Tulipani, S. and Romandini, S. (2010).Contribution of honey in nutrition and human health: A review. MediterraneanJournal of Nutrition Metabolism. 3, 15-23.

[3] Battino, M., Alvarez-Suarez, J.M. and Giampieri, F. (2013).Honey as a source of dietary antioxidants: structures, bioavailability and evidence of protective effects against human chronic diseases. Curriculum Medical Chemistry, 20, 621-638.

[4] Francisco, J.H. Terrab, A., Gonzalez, A.G. and Diez, M.J. (2003). Characterization of Morocanunifloral honeys using multivariate analysis. Journal of European Food Research and Technology, (218): 88-95.

[5] Codex Alimantarius (2001). Revised Standard for Honey. Codex Standards 12-1981. Rev. 1 1987, Rev. 2 (2001), Food and Agricultural Organization (FAO), Rome, pp. 1-21.

[6] Babacan, S., Pivarnik, L.F.and Kand, A. G., (2002). Honey Amylase activity and food starch degradation. Journal of food Science. 67 (5); 1625-1630.

[7] Sanz, M. L., Gonzalez, M., Lorenzo, C., Sanz, J., and Martinez -Castro, I. (2005). A contribution to the differentiation between nectar honey and honey dew honey. Food Chemistry.91:313-317.

[8] Adebiyi, F. M., Apkan, I., Obiajunwa, E. L. and Olaniyi, H. $\mathrm{B}(2004)$.Chemical/physical characterization of Nigeria honey.Pakistan Journal of Nutrition. 3: 27-281.

[9] Mateo, R. and Bosch, F. (1997). Sugar profiles of Spanish Unifloral Honey. Food Chemistry, 60: 33-41.

[10] Molan, P.C (1992a).The antibacterial activity of honey. 1. The nature of antibacterial activity. Bee World 73: 5-28.

[11] Lawal, R.A, Lawal, A.K. and Adekalu, J.B., (2009). Physicochemical Studies on Adulteration of Honey in Nigeria. Pakistan Journal of Biological Science, 12(15): 1080-1084.

[12] Molan, P.C. (1992b).The antibacterial activity of honey. 2. Variation in the potency of the antibacterial activity. Bee World 73: 59-76.

[13] Oladipupo, M. D. and Isah, M. C. (2009).Physical and Chemical properties of some Nigerian honey.Nigerian Journal of Research and Production.Vol. 15.No. 2.. 4.

[14] Bath, K. P. and Singh, N. (1997).Quality Evaluation of Different types of Indian honey.Food ChemistryVol; 58. No. 1 -2, pp 129-133.

[15] El-Aab, E. M. and Al-Amrony, A. Y. (2013).Physicochemical,
Heavy Metals and Phenolic compounds Analysis of Libran Honey in East Libyan Regions Journal of Science Research,pp 35-39.

[16] European Union Council (2001).Council Directive (2001)/110/EC of 20 December 2001 relating to honey.Official Journal of the European Community L10: 4752.

[17] James, O.O, Mesubi, M.A., Usman, L.A., Yeye, S.O. and Ajanaku, K.O. (2009). Physical characteristics of some honey sample from North-central Nigeria. International Journal of Physical Sciences 4: 464-470.

[18] Lawal, A. O., Adenekan, M. O., Amusa, A. N. and Okpeze, V. E. (2010). Physicochemical and Microbiological properties of Honey samples obtained from Ibadan. Journal of Microbiology and Antimicrobes. Vol. 2 (8): pp 100-104.

[19] APHA. (1995). Standard Method for the Examination of water and wastes water; American Public Health Association, Washington, DC. 541pp.

[20] AOAC (1999). Official Methods of Analysis of Association of Official Analytical Chemists. $15^{\text {th }}$ ed. Arlington Va U.S.A. AOAC. Pp 1-50.

[21] Abu-Jdayii, B. Abd Al-Majeed G., AI-Malah K.I.M.andShahera, Z. (2002). Heat effect on rtheology of light and dark-coloured honey. Journal of Food Engineering. 51(1): $33-38$

[22] Khalil, M. I., Abdulmotallib, M., Anisuzzaman, A. S. M., Sathi, Z. S., Aye, M. A. and Shahjahan, M. (2001). Journal of Medical Science. 1, 385-388.

[23] Cavia, M. M. Fernandez, M. A. and Sancho, M. T. (2004).Correlation between moisture and water activity of honey harvested in different years.Journal of Food Engineering, 72(3): 287-292.

[24] Fasasi, K. A. (2012). Physicochemical Attributes of Nigerian Natural Honey from Honey bees (Apismelliferaadansonii) Hymenoptera Apidae and its shelf life in storage at Room Temperature, Pakistan Journal of Biological Sciences 15: $1027-1033$

[25] Perez-Aguillue, C., Pilla, C., Agustin, A., Tereba, J. and Antonio, H. (1994). Quality Evaluation of Spanish rosemary (Rosemarinusofficinalis) Honey. Food Chemistry, 51: 207210.

[26] Terrab, A., B. Valdes and Diez, D.M.J. (2003). Pollen analysis of honey from Mamora Forest region (NW Morocco). Grana, 42: 47-54. 